\title{
Iodine speciation and cycling in fresh waters: a case study from a humic rich headwater lake (Mummelsee)
}

\author{
Benjamin S. GILFEDDER*, Michael PETRI ${ }^{1)}$ and Harald BIESTER \\ Institut für Umweltgeochemie, Neuenheimer Feld 236, 69120 Heidelberg, Germany \\ Present address: Institut für Umweltgeologie, Technische Universität Braunschweig, D-38023 Braunschweig, Germany \\ ${ }^{1)}$ Zweckverband Bodensee-Wasserversorgung, Betriebs- und Forschungslabor, Süßenmühle 1, 78354 Sipplingen, Germany \\ *e-mail corresponding author: Benjamin.gilfedder@tu-bs.de
}

\begin{abstract}
Iodine is a vital micronutrient for all mammals, including humans. Despite iodine's listing by the WHO as the world's most easily preventable cause of brain damage, there is very little known about iodine cycling in terrestrial freshwaters, particularly regarding temporal changes in speciation. This study presents iodine speciation (measured by IC-ICP-MS) data from one year of monthly sampling of a dimictic humic lake in the Black Forest (Mummelsee). Total soluble iodine (TSI) levels in the Mummelsee's water column averaged $1.9 \pm 0.3 \mu \mathrm{g} \mathrm{L} \mathrm{L}^{-1}$. Soluble organically bound iodine (SOI) accounted for the majority of TSI in the lake (85 $\pm 7 \%$ ) and inflow $(76 \pm 6 \%)$. SOI showed few changes throughout the year, despite stratification, anoxia in the hypolimnion and ice cover. Iodide was lost from the epilimnion during the summer, autumn and winter, which may be related to (micro)biological uptake and sedimentation of dead organic matter. Efficient biological uptake was also suggested by a sediment core, where we found high total iodine concentrations (av. $11.8 \pm 1.7 \mathrm{mg} \mathrm{kg}^{-1}$ ) and a significant correlation with organic carbon content $(\mathrm{p}<0.001)$. In the hypolimnion a strong iodide flux was observed from the sediments into the water column during lake stratification and low DO levels. Based on $I / C_{\text {org }}$ ratios in the sediment core, the iodide flux into the lake probably occurs by biological decomposition of organic material in the upper $20 \mathrm{~cm}$ of the sediments. Iodate levels in the epilimnion increased consistently over the year, whereas it was reduced below detection limits in the hypolimnion during anoxia. The winter turnover lead to reintroduction of oxygen into the hypolimnion and rapid formation of iodate and SOI. During the turnover event, near complete loss of iodide from the water column was also observed. SOI will play the largest role in iodine cycling in the Mummelsee; however, further studies are needed on the biological transformation of iodine species in freshwaters for a more complete understanding of iodine cycling.
\end{abstract}

Key words: iodine cycling, iodine and lakes, organically bound iodine

\section{INTRODUCTION}

Iodine is an essential trace nutrient for all mammals, regulating the metabolism's basal rate and building nerve cells in the brain. Insufficient iodine uptake is listed by the World Heath Organisation "as the worlds most prevalent, yet easily preventable, causes of brain damage" (Andersson et al. 2007). Iodine deficiency disorders (IDD) are thought to effect up to 2 billion people through such disorders as goitre and cretinism. IDDs affect both developed (e.g., Europe, see Andersson et al. (2007)) and developing countries [e.g., Himalayan region (Stewart 1990; de Benoist et al. 2004)].

There are 37 known iodine isotopes, ranging from ${ }^{108} \mathrm{I}$ to ${ }^{144} \mathrm{I}$, of which only ${ }^{127} \mathrm{I}$ is stable. The radioactive isotopes have varying half lives ranging from $\mu \mathrm{s}$ to millions of years. Nuclear waste reprocessing, nuclear weapons testing and nuclear power plant accidents have released the longer lived of these radioactive isotopes into the environment. For example, ${ }^{129} \mathrm{I}\left(\mathrm{t}_{1 / 2} 15.7 \mathrm{Ma}\right)$ is expected to accumulate in the environment (Reithmeier et al. 2006) without presenting a major health threat due to its very low-energy beta emissions. In contrast ${ }^{131} \mathrm{I}$ is only short lived ( $\mathrm{t}_{1 / 2} \sim 8$ days) but due to its high energy beta radiation represents a possible radiological hazard over short time scales (Howard et al. 1993). It is thought that by studying the behaviour of natural, stable, ${ }^{127} \mathrm{I}$ it may be possible to elucidate processes relating to its radioactive analogs without introducing them into the environment.

Iodine species can exist in a number of oxidation states, ranging from $\mathrm{I}^{-}$to $\mathrm{I}^{5+}\left(\right.$ as $\left.\mathrm{IO}_{3}{ }^{-}\right)$. The intermediate inorganic species between iodide and iodate are very short lived in natural environments, and thus cannot be measured directly. Under oxidizing conditions typical for well mixed lake and ocean water iodate should thermodynamically be the only inorganic iodine species detectable, with a calculated $\mathrm{IO}_{3}^{-} / \mathrm{I}^{-}$ratio of $\sim 10^{15}$ (Luther et al. 1995). However, disequilibrium has been measured in both freshwater and oceanic environments, where significant concentrations of iodide $(0.3-20 \mu \mathrm{g}$ $\mathrm{L}^{-1}$ ) have consistently been observed. This has largely been attributed to biological activity and perhaps also to photolytic processes (Elderfield \& Truesdale 1980; Jones \& Truesdale 1984; Jickells et al. 1988; Luther \& Cole 1988; Tian \& Nicolas 1995; Spokes \& Liss 1996; Cook et al. 2000; Wong \& Cheng 2001; Chance et al. 2007). It is also clear that organically bound iodine makes up a significant fraction of the aqueous iodine pool, particularly in near-shore, estuarine and fresh 


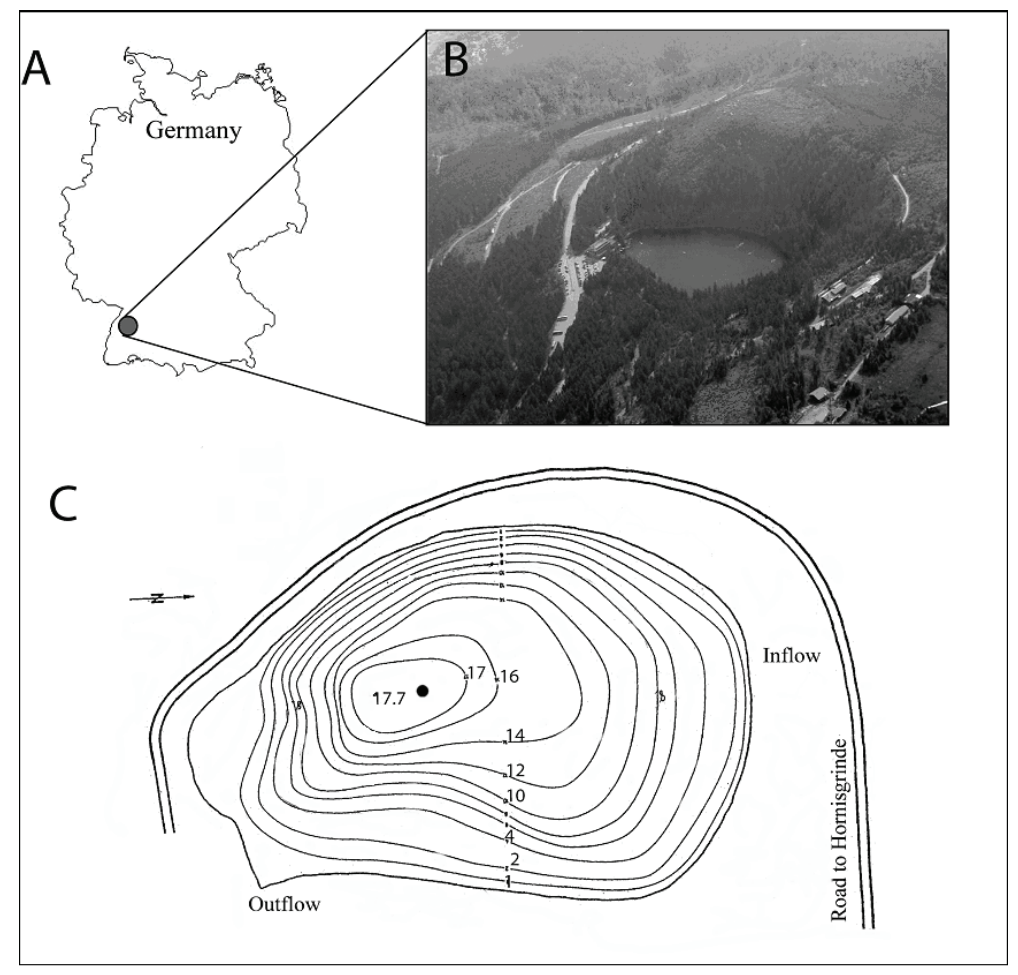

Fig. 1. A) Location of the Mummelsee in Germany. B) Aerial view of the Mummelsee and C) Schematic sketch of the lake with isobaths. Maximum width of the lake is $180 \mathrm{~m}$ and max length is $280 \mathrm{~m}$. Isobaths every 2 meters. The bathymetry map is oriented the same as the insert photo. The black point shows the sampling station.

waters as well as at the interface between oxic and anoxic waters (Ullman et al. 1990; Luther \& Campbell 1991; Stipanicev \& Branica 1996; Heumann et al. 1998; Wong \& Cheng 1998; Cook et al. 2000).

Despite iodine's importance in applied and theoretical environmental chemistry there is very little known about the natural iodine cycle in the terrestrial environment. In this regard, iodine speciation is of utmost importance. Speciation will determine the chemical behaviour of iodine and the extent with which it is able to be absorbed biologically and/or mobilized from soils and sediments. For example, iodide is thought to be rather mobile, while iodate is efficiently sorbed by soils; little is currently known about the behaviour of organically bound iodine.

Reports of total iodine concentrations in fresh waters are relatively numerous (e.g., Fuge \& Johnson 1986; Bird et al. 1995a; Oktay et al. 2001; Moran et al. 2002; Neal et al. 2007). Detailed studies focusing on speciation are less frequent and generally do not contain a temporal component (Reifenhäuser \& Heumann 1990; Rädlinger \& Heumann 1997; Heumann et al. 1998; Grüter et al. 2000; Wuilloud et al. 2003). Indeed, to our knowledge there has only been one systematic longterm study on iodine speciation in freshwater lakes (Jones \& Truesdale 1984). Jones \& Truesdale (1984) demonstrated that in the oxic zone of two lakes from the English Lakes District the iodide/iodate ratio was much higher than predicted by thermodynamics. During epi- sodes of anoxia, iodide and chloroform extractable iodine (thought to represent organic compounds and $\mathrm{I}_{2}$ ) were the only detectable iodine species. Organically bound iodine was found to be the dominant iodine species in two peat bogs from Patagonia, although this is hardly unexpected given that concentrations of dissolved organic carbon often exceed $50 \mathrm{mg} \mathrm{L}^{-1}$ and even chlorine is bound to organic moieties (Biester et al. 2006).

We present here a 12-month study on aqueous iodine speciation and cycling in the Mummelsee, a small humic rich lake in the Black Forest, Germany. The aim is to obtain a more detailed understanding of the seasonal changes in iodine speciation induced by redox and biological processes.

\section{STUDY SITE}

The Mummelsee is a small humic rich (DOC $\sim 7 \mathrm{mg}$ $\mathrm{L}^{-1}$ ) cirque lake located in the northern part of the Black Forest, Germany, at $1036 \mathrm{~m}$ a.s.l. (Fig. 1). The lake has a maximum depth of $17 \mathrm{~m}$, surface area of 3.7 ha and volume of $277500 \mathrm{~m}^{3}$. It receives groundwater inflow from a small spring located close to the lakes northern margin. This spring is derived from shallow groundwater, as the catchment is small (18 ha) and the Mummelsee is a headwater lake; located just below the summit of the highest mountain in the northern Black Forest (Hornisgrinde). Due to the low inflow, the lake has a rather long water residence time of about 470 days (calculated as lake volume divided by outflow rate, see 
Thies 1991). The catchment is mostly forested by managed Norway Spruce (Picea abies). Historically, as in many parts of the Black Forest, the Mummelsee and its catchment were affected by acid deposition, with the $\mathrm{pH}$ of the inflow and lake dropping to 4.4 and 5 respectively (Thies 1987). Its susceptibility to acid conditions is mainly due to the underlying geology (early Triassic Red Sandstone; Buntsandstein) and acid podsol soils, both of which have a low buffering capacity. Our measurements have shown that the lake has recovered since this time with the electrical conductivity (EC) dropping to $\sim 33 \mu \mathrm{S} \mathrm{cm}^{-1}$ (compared to $>100 \mu \mathrm{S} \mathrm{cm}^{-1}$ measured by Thies (1987)) and $\mathrm{pH}$ ranging from 6-7 (Gilfedder, unpublished data 2005).

\subsection{Sampling and analytical methods}

\subsubsection{Water samples}

The Mummelsee and its inflow were sampled monthly using a UWITEC 1L depth profile sampler between April 2005 and May 2006. Water samples were taken in $1 \mathrm{~m}$ intervals from the surface to the maximum water depth (17 m; Fig. 1). It was not possible to sample in December 2005 and March and April 2006 when the lake was covered with a thin layer of ice. When the lake was frozen in January and February 2006 samples were taken by drilling (Mora of Sweden ice drill) a hole through the snow and ice. The temperature was recorded from the thermometer installed in the sampler, $\mathrm{EC}$, and after the first 4 months dissolved oxygen (DO) was also recorded in the field using electrodes with inbuilt temperature correction from WTW GmbH. All samples for iodine and dissolved metals ( $\mathrm{Fe}, \mathrm{Mn}, \mathrm{Si}, \mathrm{Al})$ were filtered in the field $(0.45 \mu \mathrm{m}$ cellulose acetate $)$ into separate $50 \mathrm{~mL}$ Falcon $^{\mathrm{TM}}$ sample. Unfiltered samples were also collected for metal analysis to study the partitioning of metals between particulate $(>0.45 \mu \mathrm{m})$ and dissolved $(<0.45 \mu \mathrm{m})$ phases. This data was used to qualitatively trace redox changes in the lake. For example, it is expected that dissolved $\mathrm{Mn}^{2+}$ will be the dominant $\mathrm{Mn}$ species under anoxic conditions, whereas it will be oxidised to $\mathrm{Mn}^{4+}$ at higher oxygen levels and, due to its low solubility, partition to the particulate phase. Samples for metal analysis were acidified in the field with $1 \mathrm{~mL}$ of $65 \%$ suprapur (Merc) $\mathrm{HNO}_{3}$. The samples for iodine analysis were not acidified. All samples were kept cool at $4{ }^{\circ} \mathrm{C}$ until analysed. Storage times for iodine were usually less than two weeks but always within one month, which should be adequate to preserve the original inorganic iodine speciation (Campos 1997).

Total soluble iodine (abbreviated hereafter as TSI) concentrations were measured by inductively coupled plasma-mass spectrometry (ICP-MS) after adding ${ }^{187} \mathrm{Re}$ as an internal standard. Dissolved iodine species (iodide, iodate, and organically bound iodine) were analysed by coupling an ion chromatograph to the ICPMS (IC-ICP-MS). Soluble organically bound iodine (SOI hereafter) was calculated as total iodine minus the sum of the inorganic species (i.e., $\mathrm{SOI}=$ total $\mathrm{I}-\left(\mathrm{I}^{-}+\right.$ $\left.\mathrm{IO}_{3}^{-}\right)$). Iodine species were quantified using a Dionex AS16 column with an AG16 guard column, 35 mmol $\mathrm{NaOH}$ eluent, a flow rate of $0.9 \mathrm{~mL} \mathrm{~min}^{-1}$ and a Meinhard nebulizer with a cyclone spray chamber on a Perkin Elmer Elan 6100 quadrupole ICP-MS. Samples were injected into the chromatographic system with a Perkin Elmer series 200 autosampler and the entire system was operated by Chromera software (Perkin Elmer). This method has a detection limit ( 3 sigma) for iodide and iodate of about $30 \mathrm{ng} \mathrm{L}^{-1}$ (depending slightly on column age). Memory effects were evaluated by periodically running blank samples between regular samples. The concentrations of all iodine species in blanks were consistently below detection limits. The precision of the TSI measurements were assessed by running replicates for selected samples from most sample batches. Relative standard deviations (RSD) ranged from of $<1 \%$ to a maximum of $6 \%$. Eight replicates for iodide and iodate were run for a sample from the epilimnion over two days. Iodate, at an average of $0.15 \mu \mathrm{g} \mathrm{L}^{-1}$, gave a standard deviation (STD) of $\pm 0.006 \mu \mathrm{g} \mathrm{L}^{-1}$ and a relative standard deviation (RSD) of $4 \%$ whereas iodide, at 0.06 $\mu \mathrm{g} \mathrm{L}^{-1}$ gave a STD of $0.005 \mu \mathrm{g} \mathrm{L}^{-1}$ and a RSD of $8 \%$. The accuracy of TSI and iodide concentrations were checked using standard reference material BCR-611. BCR-611 is a groundwater certified reference material for bromide that also gives indicative values for total iodine $\left(9.3 \pm 1.3 \mu \mathrm{g} \mathrm{L}^{-1}\right)$, and iodide $\left(9.0 \pm 1.1 \mu \mathrm{g} \mathrm{L}^{-1}\right)$. All of our values were consistently within the error given in the certificate and averaged $9.7 \mu \mathrm{g} \mathrm{L}^{-1}$ for TSI and $9.4 \mu \mathrm{g} \mathrm{L}^{-1}$ for iodide. Metals were analysed using inductively coupled plasma - optical emissions spectrometry (ICP-OES). The accuracy of the calibration was checked with standard reference material NIST1643e. All concentrations available in the certificate were within 10\% (Fe 1\%, Mn 5\%, Al 9\%, Si not given) of the certificate value. Dissolved organic carbon (DOC) was measured using a TOC 5050 from Shimadzu.

\subsubsection{Sediment core}

A $42 \mathrm{~cm}$ sediment core was taken from the deepest part of the lake in October 2006 using a gravity corer (D $=15 \mathrm{~cm}, \mathrm{~L}=1 \mathrm{~m})$. The core consisted of black, organic rich sediment. The overlying water possessed a strong ' $\mathrm{H}_{2} \mathrm{~S}$ ' smell. The core was taken directly to the cool room $\left(4^{\circ} \mathrm{C}\right)$ at Heidelberg University and after three days sectioned into $1 \mathrm{~cm}$ slices in a glove bag under an $\mathrm{N}_{2}$ atmosphere. The samples were then centrifuged (15 min, $5000 \mathrm{rpm}$ ) and the supernatant removed. The remaining sediment was freeze dried, milled in an agate ball mill and analysed for total iodine concentrations as given in Gilfedder et al. (2007a). Briefly, about 20-30 $\mathrm{mg}$ of each sediment sample was placed in the quartz tube of an AOX machine and combusted in an oxygen stream at $1000{ }^{\circ} \mathrm{C}$. The released iodine vapour was then trapped in a connecting bubbler by Milli-Q water. The 
Tab. 1. ${ }^{210} \mathrm{~Pb},{ }^{214} \mathrm{Am}$ and ${ }^{137} \mathrm{Cs}$ data from the first $21 \mathrm{~cm}$ of the sediment core taken from the deepest part of the Mummelsee 2006. The sediment age inferred from the ${ }^{210} \mathrm{~Pb}$ assumes that the peak in ${ }^{214} \mathrm{Am}$ concentrations corresponds to the peak in nuclear testing in 1963 . This matches perfectly with the first peak in ${ }^{137} \mathrm{Cs}$ concentrations.

\begin{tabular}{cccccc}
\hline $\begin{array}{c}\text { Sample depth } \\
(\mathrm{cm})\end{array}$ & $\begin{array}{c}\text { Unsup. }{ }^{210} \mathrm{~Pb} \\
\left(\mathrm{~Bq} \mathrm{~kg}^{-1}\right)\end{array}$ & $\begin{array}{c}{ }^{214} \mathrm{Am}_{\left(\mathrm{Bq} \mathrm{kg}^{-1}\right)} \\
\left(\mathrm{Bq} \mathrm{kg}^{-1}\right)\end{array}$ & $\begin{array}{c}\text { Year } \\
(\mathrm{AD})\end{array}$ & $\begin{array}{c}\text { Sediment. rate } \\
\left(\mathrm{cm} \mathrm{y}^{-1}\right)\end{array}$ \\
\hline 1 & 1480.6 & 0.0 & 132.2 & & \\
2 & 1115.8 & 0.0 & 221.9 & 2005 & \\
3 & 723.8 & 0.0 & 307.4 & 1997 & 0.13 \\
4 & 558.6 & 0.0 & 565.7 & 1991 & 0.16 \\
5 & 432.4 & 0.0 & 180.1 & 1985 & 0.18 \\
6 & 395.2 & 7.0 & 228.4 & 1980 & 0.19 \\
7 & 312.8 & 5.3 & 213.6 & 1975 & 0.18 \\
8 & 336.6 & 10.6 & 250.7 & 1969 & 0.19 \\
9 & 311.5 & 23.6 & 388.6 & 1963 & 0.15 \\
10 & 247.8 & 18.7 & 175.2 & 1955 & 0.13 \\
11 & 221.3 & 6.4 & 71.2 & 1947 & 0.12 \\
12 & 122.9 & 0.9 & 32.1 & 1937 & 0.11 \\
13 & 75.5 & 0.0 & 32.1 & 1930 & 0.15 \\
14 & 65.3 & 0.0 & 31.2 & 1925 & 0.20 \\
15 & 69.1 & 0.0 & 27.1 & 1920 & 0.20 \\
16 & 62.8 & 0.0 & 20.9 & 1914 & 0.16 \\
17 & 82.2 & 0.0 & 19.6 & 1907 & 0.14 \\
18 & 45.4 & 0.0 & 24.3 & 1894 & 0.08 \\
19 & 52.8 & 0.0 & 15.5 & 1884 & 0.10 \\
20 & 39.5 & 0.0 & 14.1 & 1867 & 0.06 \\
21 & 32.5 & 0.0 & 11.8 & 1841 & 0.04 \\
\hline
\end{tabular}

solutions were analysed by an As-Ce spectrometric method whereby iodide quantitatively catalyses the reduction of $\mathrm{Ce}^{4+}$ by $\mathrm{As}^{3+}$ and the reaction rate is measured at $436 \mathrm{~nm}$ after a pre-selected reaction time in a $\mathrm{UV} / \mathrm{Vis}$ spectrometer. Standard reference materials, Chinese stream sediment (NCS DC 73312) and Chinese soil (NCS DC 73321), were analysed to ensure the accuracy of the method. Also, each second sample was measured in triplicate to assess the precision of the method. This is given as 1 standard deviation of the mean in figure 5 and was, in nearly all cases, less than $5 \%$. Two samples had a relative standard deviation of $<7 \%$. Total carbon was analysed with a LECO $\mathrm{C} / \mathrm{S}$ analyser. As this humic lake displays circum neutral $\mathrm{pH}$ values (6-7) total carbon was assumed to be solely composed of organic carbon, and the term ' $\mathrm{C}_{\text {org' }}$ ' is used throughout this manuscript. This assumption is confirmed by total organic carbon measurement from the Mummelsee compiled by Roßknecht (1992). The first $21 \mathrm{~cm}$ of the core was dated by ${ }^{210} \mathrm{~Pb}$ [Ultralow background gamma ray spectrometer (Canberra)] using the constant rate of supply model. Information on the dating method can be found in table 1 .

\section{RESULTS}

\subsection{Inflow}

The spring water was consistently oxygen saturated, as it cascaded over a small waterfall before entering the lake. Total soluble iodine (TSI) concentrations averaged $1.6 \pm 0.28 \mu \mathrm{g} \mathrm{L}^{-1}$ and apart from one high concentration in spring 2005 , levels were relatively uniform throughout the year (Fig. 2). Soluble organic iodine (SOI) was the dominant iodine fraction in the inflow, accounting for $76 \pm$ $6 \%$ of the TSI. Iodate displayed higher concentrations than iodide in all of the samples (molar $\mathrm{IO}_{3}{ }^{-} / \mathrm{I}^{-}$range from 2.756.7; Fig. 2), except for one sample from late autumn 2005 where the ratio was $\sim 0.6$. Iodide concentrations increased from the summer to late autumn (Fig. 2).

\subsection{Temperature profiles and stratification}

Thermal and chemical profiles in Mummelsee suggest that the lake is dimictic (Figs 3 and 4). In 2005, temperature, $\mathrm{Fe}$ and $\mathrm{Mn}$ profiles suggest spring overturn occurred shortly before April. As the spring and summer progressed, the lake became strongly stratified with the epilimnion reaching $3 \mathrm{~m}$ depth and the thermocline extending to $9 \mathrm{~m}$. Late autumn and winter cooling of surface water caused a second overturn and inverse stratification, although this mixing event appeared to be incomplete, only extending to $15 \mathrm{~m}$. The spring 2006 overturn differed from the previous year in that only the upper $15 \mathrm{~m}$ or so where well mixed, with the bottom waters remaining anoxic. In addition to the oxygen levels, incomplete mixing was suggested by depth profiles for redox sensitive elements $\mathrm{Fe}$ and $\mathrm{Mn}$. These elements increased in concentration from $\mathrm{Fe}$ $<100 \mu \mathrm{g} \mathrm{L}^{-1}$ and $\mathrm{Mn}<10 \mu \mathrm{g} \mathrm{L}^{-1}$ in the epilimnion to $\mathrm{Fe}$ $>2 \mathrm{mg} \mathrm{L}^{-1}$ and $\mathrm{Mn}>80 \mu \mathrm{g} \mathrm{L}^{-1}$ in the anoxic zone during both incomplete mixing events. Due to space limitations the metal profiles are not shown, but can be obtained from the first author. 


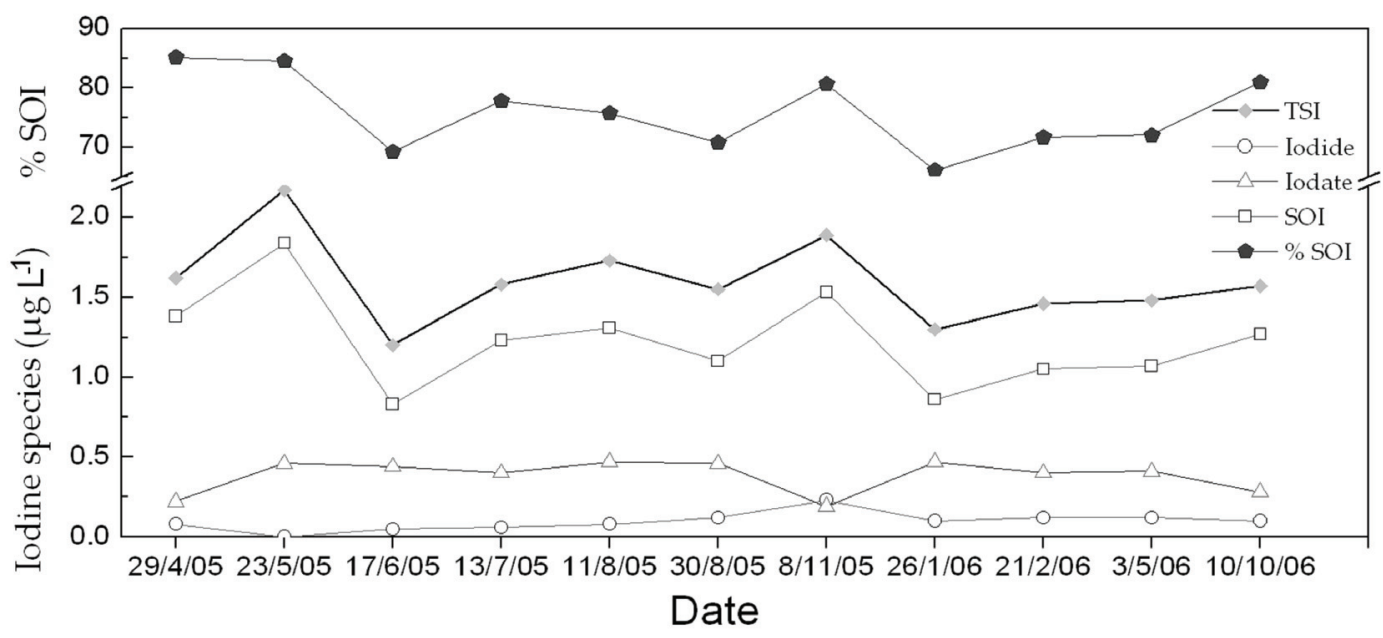

Fig. 2. Time series of total soluble iodine (TSI), soluble organically bound iodine (SOI), iodide and iodate concentrations in the inflow to the Mummelsee.

\subsection{Iodine speciation: Spring-Summer-Autumn}

Thermal stratification and oxygen depletion in the hypolimnion during summer and autumn had a large influence on dissolved iodine concentrations and speciation in the Mummelsee (Fig. 3). TSI and iodine species were relatively uniformly distributed throughout the profile after the 2005 turnover event. TSI averaged 1.88 $\pm 0.06 \mu \mathrm{g} \mathrm{L}^{-1}$ over the $17 \mathrm{~m}$ profile and iodide and iodate where approximately equal in concentration $(\sim 0.1$ $\left.\mu \mathrm{g} \mathrm{L}^{-1}\right)$. SOI concentrations in the epilimnion were relatively uniform over the spring-summer-autumn period (av. $1.6 \pm 0.15 \mu \mathrm{g} \mathrm{L}^{-1} ; 85 \pm 7 \%$ of TSI) apart from a slight depletion with depth in the epilimnion during spring and an increase in this same area in during summer (Fig. 3). In the hypolimnion SOI declined during September and October. SOI was consistently the dominant iodine species in the lake over the study period accounting for $70-95 \%$ of the TSI. The lower percentages were from the hypolimnion where increasing iodide concentrations during stratification diluted the organically bound iodine fraction.

Iodate concentrations increased in the epilimnion in the spring, which continued through the summer (maximum iodate concentration of $0.18 \mu \mathrm{g} \mathrm{L}^{-1}$ ) until the autumn-winter overturn. The iodate-enriched zone extended to a maximum depth of $8 \mathrm{~m}$, observed in the November depth profile. In contrast, iodate levels decreased to the detection limit in the hypolimnion in the summer and autumn, with the change occurring at the epi- hypolimnion boundary.

Iodide concentrations began to decrease in the lake's epilimnion over the summer-autumn period until its concentrations in the epilimnion were, by August, below the detection limit. The diminishing iodide concentrations in the epilimnion were paralleled by a large increase in the hypolimnion, where concentrations rose from $\sim 0.15 \mu \mathrm{g} \mathrm{L}^{-1}$ after the spring turnover 2005 to 0.8 $\mu \mathrm{g} \mathrm{L}^{-1}$ in late summer and autumn. Moreover, iodide concentrations diminished consistently with height above the lake bottom, with a very distinct boundary between the epi- and hypolimnion. The chemical separation (i.e., redox boundary inferred from the $\mathrm{I}^{-} / \mathrm{IO}_{3}{ }^{-}$ ratio, $\mathrm{Mn}_{\text {part }} / \mathrm{Mn}_{\text {dis }}, \mathrm{Fe}$ and $\mathrm{O}_{2}$ ) between the epilimnion and the hypolimnion became progressively more pronounced throughout the year. However, the increase in iodide cannot be solely related to iodate reduction, as, at most, this could account for $\sim 0.1 \mu \mathrm{g} \mathrm{L}^{-1}$ of the iodide. The increase in iodide concentrations in the hypolimnion was also matched by a rise in $\mathrm{Fe}, \mathrm{Mn}, \mathrm{Si}$ and a decrease in dissolved oxygen concentrations (Fig. 3 ). The large rise in $\mathrm{Fe}$ in the hypolimnion was mostly in the particle phase (i.e., $>0.45 \mu \mathrm{m}$ ), whereas $\mathrm{Mn}$ showed no difference between particulate and dissolved concentrations. In contrast, in the oxic epilimnion Mn was dominantly in the particulate phase, with a sharp decline in dissolved $\mathrm{Mn}$ and an abrupt increase in particulate $\mathrm{Mn}$ at the top of the hypolimnion. This shows that the $\mathrm{Mn}_{\text {part }} / \mathrm{Mn}_{\text {dis }}$ ratio can be used as a qualitative tracer for redox conditions in the Mummelsee.

\subsection{Iodine speciation: winter and spring-2006}

The element data imply that the upper $15 \mathrm{~m}$ of the lake were well mixed during the winter turnover event, while the bottom $2 \mathrm{~m}$ remained anoxic (Fig. 4). In the well-mixed layer, iodate $\left(0.14 \mu \mathrm{g} \mathrm{L}^{-1}\right)$ and SOI $(\sim 1.7 \mu \mathrm{g}$ $\left.\mathrm{L}^{-1}\right)$ were the predominant iodine species, whereas iodide was generally below the detection limit. SOI accounted for, on average, $94 \pm 3 \%$ of the TSI. Total soluble iodine, iodide, and metal concentrations rose at about $13 \mathrm{~m}$ depth, which also coincided with the largest decrease in dissolved oxygen levels. In contrast, iodate was absent from the anoxic bottom waters and iodide concentrations increased to a maximum of $1.2 \mu \mathrm{g} \mathrm{L}^{-1}$ (Fig. 4). 

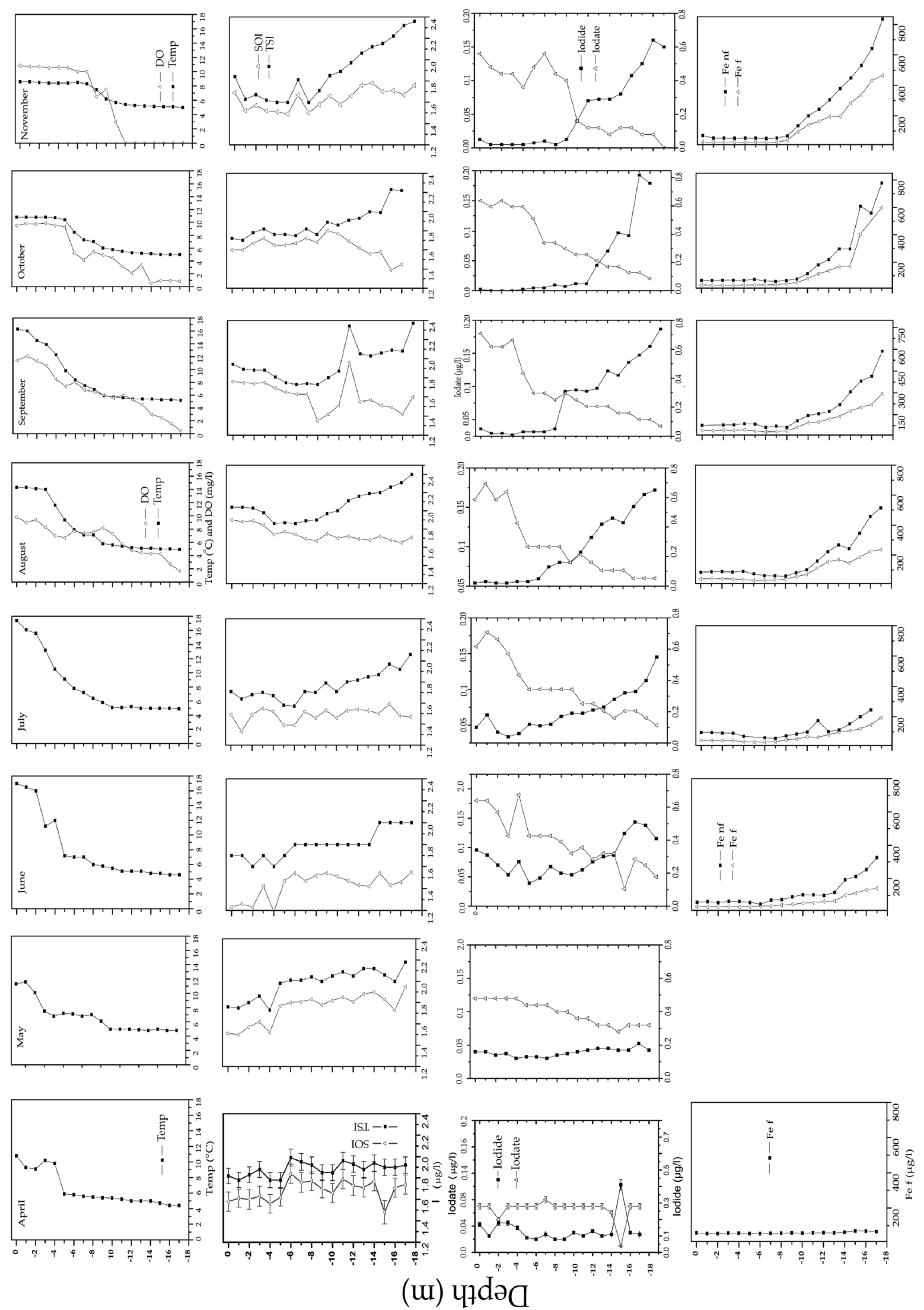

(u) पวdəа 

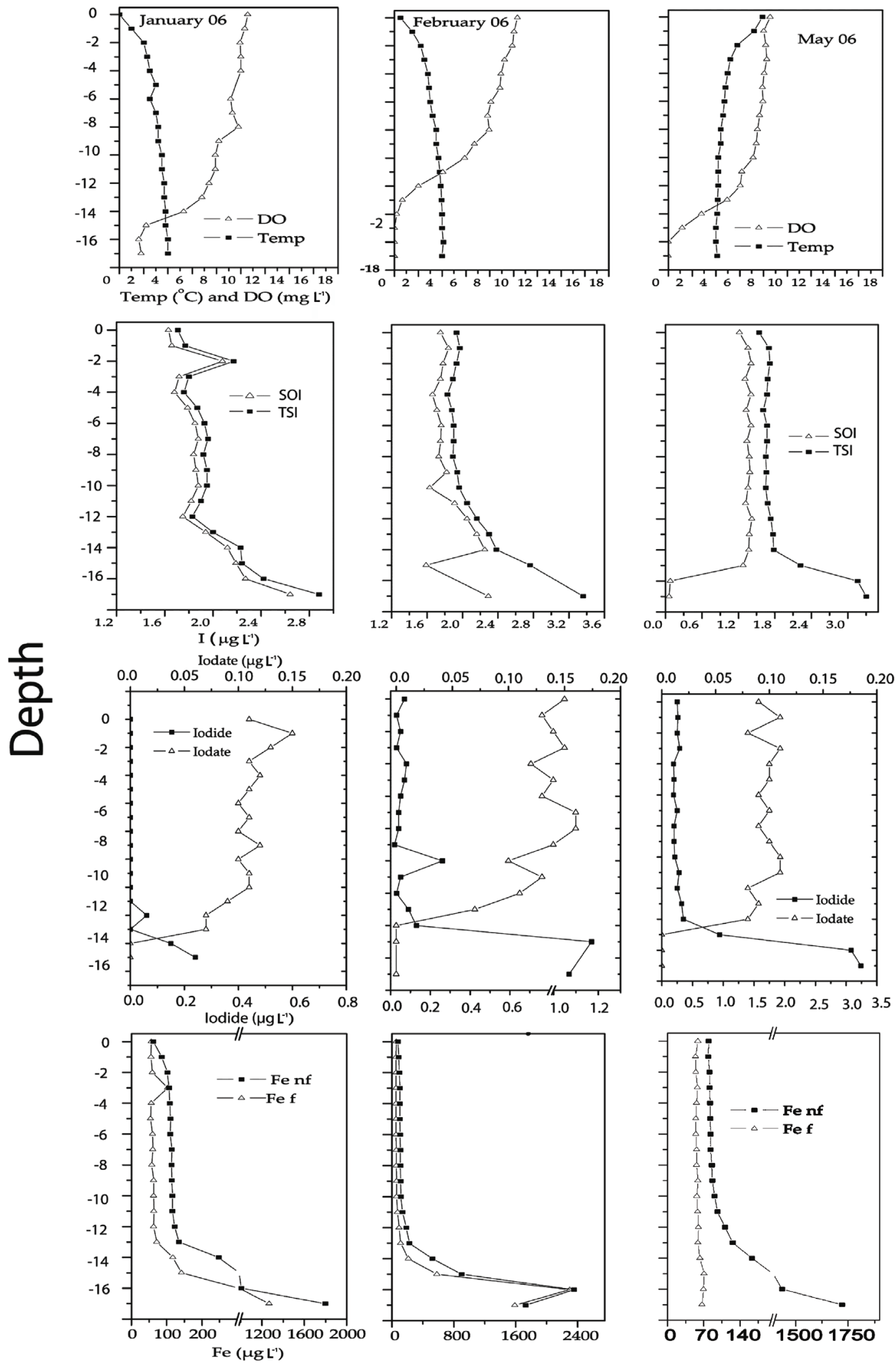

Fig. 4. Element concentrations and iodine speciation in depth profiles from the Mummelsee. Janurary 2006 to May 2006 . f= filtered, $\mathrm{nf}=$ not filtered. 

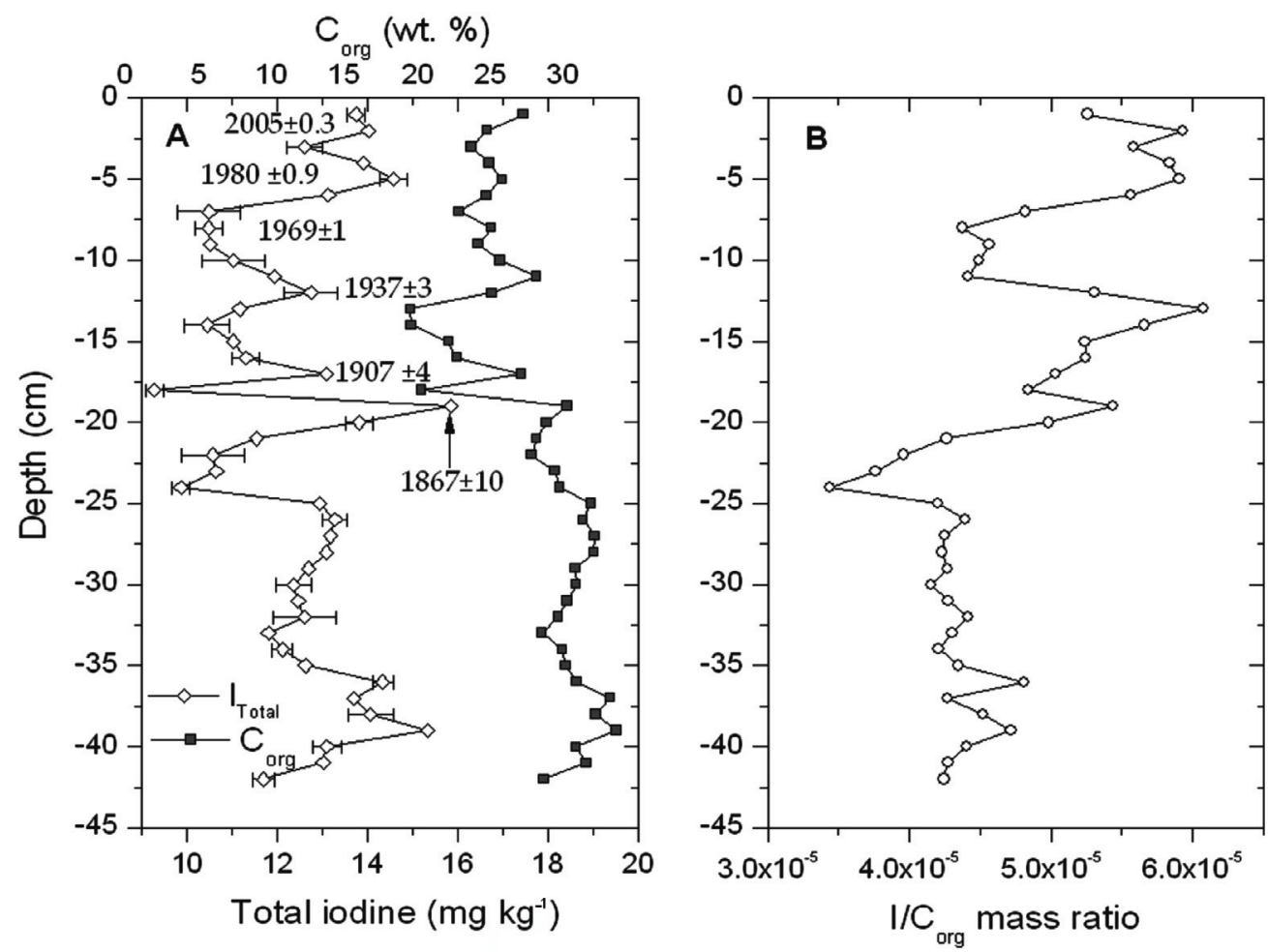

Fig. 5. A) Total iodine and total organic carbon $\left(C_{\text {org }}\right)$ concentrations and $\left.B\right)$ the $I / C_{\text {org }}$ ratio in a $42 \mathrm{~cm}$ sediment core from the Mummelsee. Error bars on total iodine represent $1 \sigma$ of triplicate analysis.

Anoxia in the bottom layers of the lake is also demonstrated by little difference between particulate and dissolved Fe and Mn levels. Qualitatively, we also noticed a strong ' $\mathrm{H}_{2} \mathrm{~S}^{\prime}$ smell. It can be clearly seen that the diffusive flux of reduced species from the bottom of the lake contributed to oxygen consumption in the overlying water column (particularly in February). Oxygen consumption was also accompanied by diffusion of iodide, $\mathrm{Mn}, \mathrm{Fe}, \mathrm{Si}$ and $\mathrm{Al}$ into the overlying water. A similar pattern was also observed after the spring 2006 turnover, with the bottom $2 \mathrm{~m}$ remaining anoxic and rich in iodide $\left(3.24 \mu \mathrm{g} \mathrm{L}^{-1}\right), \mathrm{Mn}, \mathrm{Fe}, \mathrm{Si}$ and $\mathrm{Al}$, whereas the overlying water contained higher levels of dissolved oxygen and iodate and low levels of iodide and dissolved metals (Fig. 4). Surprisingly, and in contrast to all other depth profiles, the anoxic zone in February contained nearly no SOI.

\subsection{Sediment core}

The upper $21 \mathrm{~cm}$ of the sediment core were dated by ${ }^{210} \mathrm{~Pb}$ between 2005-1867 (Tab. 1). Sedimentation rates for each centimetre in the core (calculated from ${ }^{210} \mathrm{~Pb}$ data) ranged from $0.04 \mathrm{~cm} \mathrm{y}^{-1}-0.2 \mathrm{~cm} \mathrm{y}^{-1}$. On average the sedimentation rate was $0.14 \mathrm{~cm} \mathrm{y}^{-1}$, which agrees with a previous assessment of sedimentation rates in the Mummelsee [ $0.1 \mathrm{~cm} \mathrm{y}^{-1}$; Roßknecht, (1992)]. The core contained very high concentrations of organic matter, ranging from 20-30 wt.\% Corg. Total iodine concentrations were also high, averaging $11.8 \pm 1.7 \mathrm{mg}$ $\mathrm{kg}^{-1}$, but were quite variable with depth (Fig. 5). The large variability in $\mathrm{I} / \mathrm{C}_{\text {org }}$ mass ratios in the upper $25 \mathrm{~cm}$ of the sediment core suggest that this section is actively involved microbial decomposition of organic matter and de-iodination of organoiodine compounds. In contrast, bellow this level the $\mathrm{I} / \mathrm{C}_{\text {org }}$ mass ratio tends to a constant of $\sim 4.3 \pm 0.2 \times 10^{-5}$, and thus it is suspected that bellow this depth there is little further de-iodination of the carbon substrate. The sediment $\mathrm{I} / \mathrm{C}_{\text {org }}$ mass ratios were more than 6 times lower than observed for TSI/DOC mass ratio in the water column $\left(2.7 \pm 0.5 \times 10^{-4}\right.$; Gilfedder unpublished data 2005). This must be treated with caution however, as particulate organic material may have a different $\mathrm{I} / \mathrm{C}$ ratio to the dissolved phase.

Regression analysis can be used as a quantitative treatment of the relationship between $\mathrm{C}_{\text {org }}$ and iodine in the sediment. When the entire data set is used (treating $\mathrm{C}_{\text {org }}$ as the independent variable), there is only a week $\left(r^{2}=0.28\right)$, although statistically significant $(p<0.001)$, relationship. However, as suggested by $\mathrm{I} / \mathrm{C}_{\text {org }}$ ratios, the iodine-carbon profile is made up of two sections (Fig. 6). The first section ranged from $0-21 \mathrm{~cm}$, where the iodine carbon ratio is relatively variable $\left(r^{2}=0.57 \mathrm{av}\right.$. $\left.\mathrm{I} / \mathrm{C}_{\text {org }}=5.2 \pm 0.5 \times 10^{-5}\right)$. In the next section $(25-42 \mathrm{~cm})$ the $\mathrm{I} / \mathrm{C}_{\text {org }}$ ratio tended to a constant value $\left(r^{2}=0.67\right.$ av. $\left.\mathrm{I} / \mathrm{C}_{\text {org }}=4.3 \pm 0.17 \times 10^{-5}\right)$. Both regressions were statistically significant $(p<0.001)$. The fact that the iodine concentrations in the sediment are considerably higher than in the dissolved phase, and the significant $I / C_{\text {org }}$ 


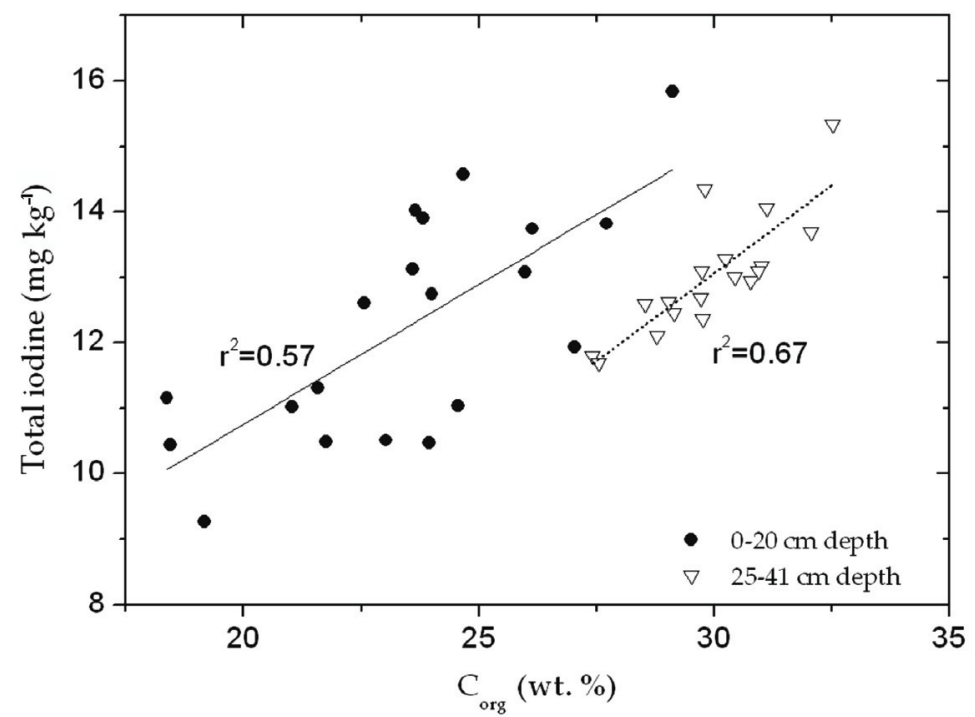

Fig. 6. Total iodine $v s \mathrm{C}_{\text {org }}$ concentrations in sediments from $0-20 \mathrm{~cm}$ and $25-42 \mathrm{~cm}$ depth.

correlations in the sediments, suggest efficient uptake and sedimentation of iodine associated with lake biota.

\section{DISCUSSION}

While most studies from freshwater environments focus on quantifying total iodine, analysis of the individual species can provide additional information on the chemical and biological processes influencing this element. In this section we first compare the TSI concentrations in the Mummelsee with other freshwater studies and then discuss iodine speciation and cycling in the lake.

\subsection{Total soluble iodine concentrations}

The TSI concentrations in the Mummelsee are similar to those reported for fresh water at other sites which are not directly influenced by marine sea spray ( few $\mathrm{km})$. The most comprehensive study on iodine concentrations in freshwater is from Neal et al. (2007), where 25 years of weekly to fortnightly iodine data of three streams located in Wales, UK, are compared. Their average TSI concentrations were found to range between 1-1.89 $\mu \mathrm{g} \mathrm{L}^{-1}$, which is very similar to the average TSI value observed in the Mummelsee $(1.92 \mu \mathrm{g}$ $\left.\mathrm{L}^{-1}\right)$. However, Neal et al. (2007) used a spectrometric method based on the catalytic effect of iodide on the reduction of $\mathrm{Ce}^{4+}$ by $\mathrm{As}^{3+}$. While this method is rapid, relatively inexpensive and has low detection limits, it has been shown by Wong \& Cheng (1998), which the authors also acknowledge, that it only quantifies the labile portion of the SOI in addition to the inorganic species. As such, it may be misleading to compare ICPMS data with Neal et al. (2007). For example, Mummelsee, located $\sim 800 \mathrm{~km}$ from the Atlantic Ocean, $\sim 500$ $\mathrm{km}$ from the North Sea and $>1000 \mathrm{~m}$ a.s.l., has a higher average iodine concentration than observed in Wales, just $20 \mathrm{~km}$ from the coast. Snyder \& Fehn (2004) have analysed (ICP-MS) one-off surface water samples from every continent in the world, with a range from 0.125 $137 \mu \mathrm{g} \mathrm{L} \mathrm{L}^{-1}$. The highest concentrations generally occurred in arid environments and thus are expected to represent evapoconcentration. TSI concentrations in the Mummelsee lie within the lower rang of fresh water samples from Europe. Iodine levels taken from rivers in northern Germany are considerably higher than observed in the Mummelsee, averaging $11.5 \mu \mathrm{g} \mathrm{L}^{-1}$ (Szidat et al. 2000; Michel et al. 2002). Atarashi-Andoh et al. (2007) have taken samples from various lakes in the English Lakes District with a range in TSI concentrations of $0.9-4.95 \mu \mathrm{g} \mathrm{L}^{-1}$ over 8 lakes. TSI concentrations in these lakes depended on season, with higher levels in autumn; a finding supported by the long-term measurements of Neal et al. (2007). A two year study by Oktay et al. (2001) presents iodine concentrations from the Mississippi that are similar to those observed in Europe, with an average (excluding unfiltered and replicate samples) of $5.55 \mu \mathrm{g} \mathrm{L}^{-1}$. In contrast, Moran et al. (2002) present an average of $\sim 20 \mu \mathrm{g} \mathrm{L}^{-1}$ for a large number of rivers in the United States of America, although this average concentration is somewhat skewed by a few rivers with very high iodine levels.

Rainwater collected from the Black Forest by Krupp \& Aumann (1999), analysed by neutron activation analysis, were only slightly higher than the lake water concentrations found in the Mummelsee, averaging 2.2 $\pm 0.8 \mu \mathrm{g} \mathrm{L}^{-1}$. Snow samples collected in 2006 from the Mummelsee's surface (Gilfedder et al. 2007b) had nearly identical concentrations $\left(1.84 \pm 0.17 \mu \mathrm{g} \mathrm{L}^{-1}\right)$ to the lake and inflow water $\left(\sim 1.9 \mu \mathrm{g} \mathrm{L}^{-1}\right)$. This suggests that the majority of iodine in the Mummelsee is derived from atmospheric deposition with little input from rocks and soils in the catchment. Undoubtedly, many factors will influence the iodine concentrations in lakes and rivers and will depend on the environmental setting. 


\subsection{Organically bound iodine}

The presence of a SOI fraction in coastal marine and terrestrial environments has only recently received attention. Moreover, in many cases SOI is the most abundant component in fresh water. Neal et al. (2007) have found indirect evidence for SOI, with strong seasonal co-variation of TSI (As-Ce method) with DOC. SOI also been observed as the major iodine fraction in a number of natural fresh waters, such as river and groundwater, and is thought to be bound to high molecular weight humic substances (Reifenhäuser \& Heumann 1990; Rädlinger \& Heumann 1997; Heumann et al. 1998; Moulin et al. 2001; Schlegel et al. 2006). It has also been noted that SOI is the dominant iodine species in aerosols, rain and snow, despite the previous view that inorganic species dominate in the atmosphere (Baker et al. 2001; Baker 2005; Gilfedder et al. 2007b, c).

The formation of SOI in the lake was most notable between July and November and during the winter turnover composing over $90 \%$ of the TSI. These temporal changes suggest that biological cycles play a central role in iodine speciation, and specifically SOI formation. Biologically mediated iodination of organic molecules is defined as both (1) bonding of iodine to carbon within the organism, and (2) indirect processes such as biologically induced oxidation of iodide to $\mathrm{I}_{2}$ (e.g., by exo/endo-enzymatic processes) which can then react with humic substances through abiotic mechanisms. Indirect biologically mediated formation of SOI could also occur by iodate reduction, where biologically produced reductants (e.g., $\mathrm{HS}^{-}$) reduce iodate to $\mathrm{HOI}$ or $\mathrm{I}_{2}$, which may then react with humic macromolecules (Francois 1987; Reiller et al. 2006). Such a mechanism has been observed at the interface between anoxic and oxic ocean waters were iodate was reduced (by sulphide) to reactive intermediate iodine species that subsequently bind to organic matter (Ullman et al. 1990; Luther \& Campbell 1991). Microbiological iodination of humic substances was shown by Rädlinger \& Heumann (2000), where inorganic iodide was transformed into organic forms after only 4 weeks of wastewater incubation. While the samples used by Rädlinger \& Heumann (2000) would have had significantly different microbiological communities than the Mummelsee, it demonstrates likelihood of microbiological iodination of organic substances. The lack of any other peaks in the anion chromatograms from both the spring inflow and the lake suggests that the iodine is bound to high molecular weight, non-ionic carbonaceous species. This is in agreement with previous studies at the Synchrotron facility, Grenoble France, where Schlegel et al. (2006) found iodine to be covalently bound to aromatic structures in natural humic substances. Similar observations were also made using mass spectrometry by Moulin et al. (2001).

The winter turnover in January 2006 converted the iodide released from the sediments during the summer to SOI. At present we do not fully understand this process, but it must be related to oxygenation of hypolimnic waters with overturn. Perhaps the introduction of oxygen to water which contained considerable amounts of ammonium (inferred from redox profiles of $\mathrm{O}_{2}, \mathrm{Fe}$ and Mn; Fig. 4) produced an outbreak of $\mathrm{NH}_{4}{ }^{+}$oxidizing bacteria. In the process of $\mathrm{NH}_{4}{ }^{+}$oxidation perhaps $\mathrm{I}^{-}$was also oxidized to reactive intermediate species such as $\mathrm{I}_{2}$ that could then react with DOC. This is rather speculative and must be confirmed or negated in future studies on biological oxidation of iodide.

\subsection{Iodide}

Iodide concentrations in the epilimnion consistently declined throughout the summer and autumn until it was below the detection limit. This suggests that iodide was removed from the upper $8 \mathrm{~m}$ of the lake. There are two possible processes for this removal: sorption by (oxy)hydroxide particles or by biological uptake. The first option is the least likely, as it has been widely observed that iodide possesses very little affinity for (oxy)hydroxids, and iron hydroxides in particular (Neal et al. 1976; Ullman \& Aller 1980). Biological uptake of iodide by organisms (photosynthetic or otherwise) in the epilimnion of the lake appears considerably more likely. Although data on biological iodide uptake from fresh water are scarce, such suggestions are supported by observations from marine environments, where iodide is generally the preferred iodine species for absorption (Sugawara \& Terada 1967). For example, Laminaria sp. is thought to enzymatically oxidize iodide to HOI within the cell wall and only then take it into cells (Küpper et al. 1998). Also, as an alternative to algal uptake, absorption by bacteria may also play an important role in iodide immobilization and removal from the water column. The potential role for bacterial uptake was highlighted by Amachi et al. (2005), where bacteria isolated from marine sediments actively absorbed iodide from solution (enrichment factors up to 6000). Moreover, Fuse et al. (2003) have also demonstrated bacterial uptake and conversion of iodide to volatile organic iodine compounds (particularly $\mathrm{CH}_{2} \mathrm{I}_{2}$ ). Moreover, Rädlinger \& Heumann (2000) have found that iodide could be bound to humic substances by microbiological processes. Therefore, it may be possible that bacteria residing in suspended particles take up iodide from the lakes water column and, on sinking of these particles, remove the iodide from the epilimnion. The near total loss of iodide and formation of SOI when the lake was covered by a thick layer of ice and snow $(>1 \mathrm{~m})$ implies that iodide loss is not related to photosynthetic activities. Due to the current lack of data on iodide uptake by either algae or bacteria in freshwater it would be useful for future studies to quantify such processes in more detail.

In contrast to the epilimnion, iodide concentrations increased significantly in the hypolimnion during sum- 
mer stratification. The increase in iodide mobility with anoxia has been well studied, particularly in marine environments (Wong \& Brewer 1977; Luther \& Cole 1988; Žic \& Branica 2006), but has also been observed in lakes and rivers (Neal \& Truesdale 1976; Jones \& Truesdale 1984; Bird et al. 1995b; Bird \& Schwartz 1996). Despite the consensus on iodide's mobility, its source in the hypolimnion of freshwater lakes has not been well documented. Jones \& Truesdale (1984), for example, were not able to elucidate if the increase in iodide observed in the hypolimnion of Esthwaite lake during anoxia came from the bottom sediments or was released from suspended particles. It is clear from figures 3 and 4 that the increase in iodide concentrations in the hypolimnion originates from diffusive flux from the lake's bottom sediments. Moreover, the $\mathrm{I} / \mathrm{C}_{\text {org }}$ ratio in the sediments is 7 times lower than in the dissolved phase, suggesting deiodination of the organic material in sediments when bottom waters are anoxic. The large variability in $\mathrm{I} / \mathrm{C}_{\text {org }}$ ratios in the upper $20 \mathrm{~cm}$ of the sediment core, and lower $\mathrm{I} / \mathrm{C}_{\text {org }}$ values bellow this depth, suggest that iodide is released into the hypolimnion from the first $20 \mathrm{~cm}$ of the sediment.

\subsection{Iodate}

The increase in iodate in the epilimnion was unexpected, as it is generally believed that iodate is reduced to iodide biologically in oxic oceanic water (perhaps by nitrate reductase; Tsunogai \& Sase 1969; Fuge 2005; Chance et al. 2006). This suggests a fundamental difference between the Mummelsee and the ocean. Photooxidation will not contribute to iodate formation in the epilimnion of the Mummelsee, as Wong \& Cheng (1998) have shown that organically bound iodine decays to iodide on exposure to natural sunlight. Moreover, it is also very difficult to oxidize iodide to iodate with $\mathrm{O}_{2}$ or even more reactive oxygen species (e.g., $\mathrm{H}_{2} \mathrm{O}_{2}$ ) as it requires removal of 6 electrons and therefore must occur in a at least 2 electron transfer steps (Luther et al. 1995). Reactions with common oxidants that could be expected in the Mummelsee in trace amounts (e.g., $\mathrm{Cl}, \mathrm{O}_{3}, \mathrm{H}_{2} \mathrm{O}_{2}$ ) only remove one electron, and thus must occur 6 times to oxidise iodide to iodate. These oxidants are also more likely to react with the DOC in the lake before reacting with iodide. Rather than oxidizing iodide to iodate, iodide may be oxidized to $\mathrm{I}_{2}$ or HOI, which can subsequently react to form covalent bonds with DOC. Therefore, we are only left with the possibility of a biologically mediated reaction for iodate formation.

Due to the lack of data on iodate formation in freshwater we must rely on studies from marine environments. Surprisingly, the majority of research has focused on iodate reduction rather than iodide oxidation, despite the majority of the oceans iodine in ocean water existing as iodate. Based on a mass-balance of iodine species fluxes in the Black Sea, Truesdale et al. (2001) have suggested that iodide may be oxidized to iodate by nitrifying bacteria. Biologically mediated iodate formation is also consistent with our results, as the largest increase in iodate was found in the top three meters of water, which is essentially the maximum light penetration depth and also has the highest oxygen levels. However, light must not be essential for the organisms, as during winter when the lake was covered by $>1 \mathrm{~m}$ of snow and ice, iodate could still be found down to about $13 \mathrm{~m}$ depth at concentrations similar to those found in the epilimnion over the summer months. As such, we suggest that rapid microbiological production of iodate must occur with the winter turnover, although unrelated to photosynthetic production.

One of the most noticeable processes occurring in the Mummelsee is iodate reduction in the hypolimnion. Iodate reduction was probably coupled to release of reduced species (such as $\mathrm{H}_{2} \mathrm{~S}$ ) from the sediments (JiaZhong \& Whitfield 1986). Jia-Zhong \& Whitfield (1986) found that the reaction rate of $\mathrm{IO}_{3}^{-}$with $\mathrm{HS}^{-}$is faster than the reaction between $\mathrm{O}_{2}$ and $\mathrm{HS}^{-}$and as such does not require completely anoxic conditions to proceed. The reduction of iodate by reduced sulphur compounds such as sulphide has also been noted in marine environments, and particularly in biologically productive estuaries, marine enclosures and deep anoxic ocean water (Wong \& Brewer 1977; Luther \& Cole 1988; Luther \& Campbell 1991; Stipanicev \& Branica 1996). However, it is unlikely that the iodate is reduced to iodide in the Mummelsee, as it must first be reduced to the highly reactive and electrophilic $\mathrm{I}_{2}$ species, which will then rapidly react with DOC compounds (JiaZhong \& Whitfield 1986). Such processes are often observed at the oxic-anoxic boundary in certain marine basins such as the Mediterranean Sea and the Black Sea (Ullman et al. 1990; Luther \& Campbell 1991). Iodate reduction cannot be a strong source of SOI in the Mummelsee, as the maximum iodate concentrations in the hypolimnion just after mixing are about $0.1 \mu \mathrm{g} \mathrm{L}^{-1}$.

\section{ACKNOWLEDGEMENTS}

We would like to thank the Berg Hotel at the Mummelsee for allowing us to use their tourist boats for sampling and student Jessica Gutknecht for help with sampling on two occasions. Christian Schultz is also thanked for help with the ICP-OES measurements. The two reviewers are also thanked for improving the previous version of the manuscript. This project was funded by the Deutsche Forschungsgemeinschaft to $\mathrm{H}$. Biester under contract No. BI-734/4-5.

\section{REFERENCES}

Amachi, S., Y. Mishima, H. Shinoyama, Y. Muramatsu \& T. Fujii. 2005. Active transport and accumulation of iodide by newly isolated marine bacteria. Appl. Environ. Microbiol., 71(2): 741-745.

Andersson, M., B. de Benoist, I. Darnton-Hill \& F. Delange. 2007. Iodine deficiency in Europe: a continuing public health problem. Geneva, World Health Organization: 86 pp. 
Atarashi-Andoh, M., C. Schnabel, G. Cook, A. B. MacKenzie, A. Dougans, R. M. Ellam, S. Freeman, C. Maden, V. Olive, H.A. Synal \& S. Xu. 2007. ${ }^{129} \mathrm{I} /{ }^{127} \mathrm{I}$ ratios in surface waters of the English Lake District. Appl. Geochem., 22: 628-636.

Baker, A. R. 2005. Marine aerosol iodine chemistry: the importance of soluble organic iodine. Environ. Chem., 2: 295-298.

Baker, A. R., C. Tunnicliffe \& T. D. Jickells. 2001. Iodine speciation and deposition fluxes from the marine atmosphere. J. Geophys. Res., 106(D22): 28743-28749.

Biester, H., D. Selimovic, S. Hemmerich \& M. Petri. 2006. Halogens in pore water of peat bogs - the role of peat decomposition and dissolved organic matter. Biogeosciences, 3: 53-64.

Bird, G.A., M. Motycka, J. Rosentreter, W.J. Schwartz \& P. Vilks. 1995a. Behavior of ${ }^{125} \mathrm{I}$ added to limnocorrals in two Canadian Shield lakes of differing trophic states. Sci. Total Environ., 166: 161-177.

Bird, G.A. \& W.J. Schwartz. 1996. Distribution coefficients, Kds, for iodine in Canadian Shield lake sediment under oxic and anoxic conditions. J. Environ. Radioact., 35(3): 261-279.

Bird, G.A., W.J. Schwartz \& J. Rosentreter. 1995b. Evolution of ${ }^{131} \mathrm{I}$ from freshwater and its partitioning in simple aquatic microcosms. Sci. Total Environ., 164: 151-159.

Campos, M.L.A.M. 1997. New approach to evaluating dissolved iodine speciation in natural waters using cathodic stripping voltammetry and a storage study for preserving iodine species. Mar. Chem., 57: 107-117.

Chance, R., G. Malin, T.D. Jickells \& A.R. Baker. 2007. Reduction of iodate to iodide by cold water diatom cultures. Mar. Chem., 105: 169-180.

Cook, P.L. M., P.D. Carpenter \& E.C.V. Butler. 2000. Speciation of dissolved iodine in the waters of a humic-rich estuary. Mar. Chem., 69: 179-192.

de Benoist, B., A. Andersson, I. Egli, B. Takkouche \& H. Allen. 2004. Iodine status worldwide. Geneva, World Health Organization: $46 \mathrm{pp}$.

Elderfield, H. \& V.W. Truesdale. 1980. On the biophilic nature of iodine in seawater. Earth. Planet. Sci. Lett., 50: 105-114.

Francois, R. 1987. The influence of humic substances on the geochemistry of iodine in nearshore and hemipelagic marine sediments. Geoch. Cosmochim. Acta, 51: 2417-2427.

Fuge, R. 2005. Soils and iodine deficiency. In: O. Selinus (Ed.), Essentials of medical geology: impacts of the natural environment on public health. Heidelberg, Elsevier Academic Press: 417-433.

Fuge, R. \& C.C. Johnson. 1986. The geochemistry of iodine a review. Environ. Geochem. Health, 8(2): 31-54.

Fuse, H., H. Inoue, K. Murakami, O. Takimura \& Y. Yamaoka. 2003. Production of free and organic iodide by Roseovarius spp. FEMS Microbiol. Lett., 229: 189-194.

Gilfedder, B.S., F. Althoff, M. Petri \& H. Biester. 2007a. A thermo extraction-UV/Vis spectrophotometric method for total iodine quantification in soils and sediments. Anal. Bioanal. Chem., 389(7-8): 2323-2329. doi: 10.1007/ s00216-007-1621-4.

Gilfedder, B.S., M. Petri \& H. Biester. 2007b. Iodine and bromine speciation in snow and the effect of orographically induced precipitation. Atmos. Chem. Phys., 7: 26612669.

Gilfedder, B.S., M. Petri \& H. Biester. 2007c. Iodine speciation in rain and snow: Implications for the atmospheric iodine sink. J. Geophys. Res., 112. doi:10.1029/ 2006JD007356.

Grüter, U.M., J. Kresimon \& A.V. Hirner. 2000. A new HG/LT-GC/ICP-MS multi-element speciation technique for real samples in different matrices. Fresenius J. Anal. Chem., 368: 67-72.
Heumann, K.G., S.M. Gallus, G. Rädlinger \& J. Vogl. 1998. Accurate determination of element species by on-line coupling of chromatographic systems with ICP-MS using isotope dilution technique. Spectrochim. Acta Part B, 53: 273-287.

Howard, B.J., N.A. Beresford, R.W. Mayes \& C.S. Lamb. 1993. Transfer of 131I from sheep milk from vegetation contaminated by Chernobyl Fallout. J. Environ. Radioactivity, 19: 155-161.

Jia-Zhong, Z. \& M. Whitfield. 1986. Kinetics of inorganic redox reactions in seawater: 1 . The reduction of iodate by bisulphide. Mar. Chem., 19: 121-137.

Jickells, T.D., S.S. Boyd \& A.H. Knap. 1988. Cycling in the Sargasso Sea and the Bermuda inshore waters. Mar. Chem., 24: 61-82

Jones, S.D. \& V.W. Truesdale. 1984. Dissolved iodine species in a British freshwater systems. Limnol. Oceanogr., 29(5): 1016-1024.

Krupp, G. \& D.C. Aumann. 1999. The origin of iodine in soil: I. Iodine in rainfall over Germany. Chem. Erde, 59: 57-67.

Küpper, F.C., N. Schweigert, E. Ar Gall, J.M. Legendre, H. Vilter \& B. Kloareg. 1998. Iodine uptake by Laminariales involves extracellular, haloperoxidase-mediated oxidation of iodide. Planta, 207: 163-171.

Luther, G.W. \& T. Campbell. 1991. Iodine speciation in the water column of the Black Sea. Deep-Sea Res, 38(suppl. 2): S875-S882.

Luther, G.W. \& H. Cole. 1988. Iodine speciation in Chesapeake Bay waters. Mar. Chem., 24: 315-325.

Luther, G.W., J. Wu \& J.B. Cullen. 1995. Redox chemistry of iodine in seawater: frontier molecular orbital theory considerations. In: C.P. Huang, C.R. O'Melia \& J.J. Morgan (Ed.), Aquatic Chemistry: interfacial and interspecies processes. Washington DC, American Chemical Society.

Michel, R., T.H. Ernst, D. Jackob, K. Klipsch, S. Szidat, H.A. Synal \& C. Schnabel. 2002. Long-lived radionuclides in the environment: The case of iodine-129. EUROSAFE, Berlin, http://www.eurosafe-forum.org/products/data/5/ pe 235241 euro2 42 iodine129.pdf?PHPSESSID=93 $3 \mathrm{~d} \bar{f} \mathrm{c} 3 \mathrm{de} 630 \overline{\mathrm{a}} \overline{5} 55 \mathrm{e} 39 \overline{\mathrm{b}} \overline{8} 1 \overline{6} 57 \mathrm{~d} 2 \mathrm{af} 29$.

Moran, J.E., S.D. Oktay \& P.H. Santschi. 2002. Sources of iodine and iodine 129 in rivers. Water Resour. Res., 38(8): $1-10$.

Moulin, V., P. Reiller, B. Amekraz \& C. Moulin. 2001. Direct characterization of iodine covalently bound to fulvic acids by electrospray mass spectrometry. Rapid Commun. Mass Spectrom., 15: 2488-2496.

Neal, C., M. Neal, H. Wickham, L. Hill \& S. Harman. 2007. Dissolved iodine in rainfall, cloud, stream and groundwater in the Plynlimon area of mid-Wales. Hydrol. Earth Sys. Sci., 11(1): 283-293.

Neal, C. \& V.W. Truesdale. 1976. The sorption of iodate and iodide by riverine sediments: its implications to dilution gauging and hydrochemistry of iodine. J. Hydrol., 31: 281-291.

Oktay, S.D., P.H. Santschi, J.E. Moran \& P. Sharma. 2001. ${ }^{129} \mathrm{I}$ and ${ }^{127} \mathrm{I}$ transport in the Mississippi River. Environ. Sci. Technol., 35: 4470-4476.

Rädlinger, G. \& K.G. Heumann. 1997. Determination of halogen species of humic substances using HPLC/ICP-MS coupling. Fresenius J. Anal. Chem., 359: 430-433.

Rädlinger, G. \& K.G. Heumann. 2000. Transformation of iodide in natural and wastewater systems by fixation on humic substances. Environ. Sci. Technol., 34: 3932-3936.

Reifenhäuser, C. \& K.G. Heumann. 1990. Development of a definitive method for iodine speciation in aquatic systems. Fresenius J. Anal. Chem., 336: 559-563.

Reiller, P., F. Mercier-Bion, N. Gimenez, N. Barre \& F. Miserque. 2006. Iodination of humic acid samples from different origins. Radiochim. Acta, 94: 739-745. 
Reithmeier, H., V. Lazarev, W. Rühm, M. Schwikowski, H.W. Gäggeler \& E. Nolte. 2006. Estimate of European ${ }^{129} \mathrm{I}$ Releases Supported by ${ }^{129}$ I Analysis in an Alpine Ice Core. Environ. Sci. Technol., 40(19): 5891 -5896.

Roßknecht, H. 1992. Chemische untersuchungen des wassers und der sediment von 44 seen in Baden-Württemberg. Stuttgart, Umweltministerium Baden-Württemberg.

Schlegel, M.L., P. Reiller, F. Mercier-Bion, N. Barre \& V. Moulin. 2006. Molecular environment of iodine in naturally iodinated humic substances: Insights from X-ray absorption spectroscopy. Geochim. Cosmochim. Acta, 70: 5536-5551.

Schwehr, K.A. \& P.H. Santschi. 2003. Sensitive determination of iodine species, including the organo-iodine, for freshwater and seawater samples using high performance liquid chromatography and spectrophotometric detection. Anal. Chim. Acta, 482: 59-71.

Snyder, G. \& U. Fehn. 2004. Global distribution of 129I in rivers and lakes: implications for iodine cycling in surface reservoirs. Nucl. Instrum. Methods Phys. Res. Sect. B, 223-224: 579-586.

Spokes, L.J. \& P.S. Liss. 1996. Photochemically induced redox reaction in seawater, II: nitrogen and iodine. Mar. Chem., 54: 1-10.

Stewart, A. 1990. For debate: Drifting continents and endemic goiter in northern Pakistan. British Medical Journal, 300(9 June): $1507-1512$.

Stipanicev, V. \& M. Branica. 1996. Iodine speciation in the water column of the Rogoznica Lake (Eastern Adriatic Coast). Sci. Total Environ., 182: 1-9.

Sugawara, K. \& K. Terada. 1967. Iodine assimilation by a marine Navicula $\mathrm{sp}$. and the production of iodate accompanied by the growth of the algae. Information Bulletin on Planktology in Japan: 213-218.

Szidat, S., A. Schmidt, J. Handl, D. Jackob, W. Botsch, R. Michel, H.A. Synal, C. Schnabel, M. Suter, J.M. LópezGutiérrez \& W. Städe. 2000. Iodine-129: sample preparation, quality control and analysis of pre-nuclear materials and of natural waters from Lower Saxony, Germany. Nucl. Instrum. Methods Phys. Res. Sect. B, 172: 699-710.

Thies, H. 1987. Limnochemische Unterschungen an vier Karseen des Nordschwarzwalds unter Berücksichtigung von sauren Niederschlägen sowie der Makrophytenvegetation. Limnologischen Institut Konstanz. Freiburg, University of Freiburg: 329 pp.

Thies, H. 1991. Limnochemical studies at small Black Forest Lakes (FRG) with special emphasis to acidification. Verh. Internat. Verein. Limnol., 24: 806-809.

Tian, R.C. \& E. Nicolas. 1995. Iodine speciation in the northwestern Mediterranean Sea: method and vertical profile. Mar. Chem., 48: 151-156.

Truesdale, V.W., S.F. Watts \& A.R. Rendell. 2001. On the possibility of iodide oxidation in the near surface of the Black Sea and its implications to iodine in general oceans. Deep-Sea Res., 48: 2397-2412.

Tsunogai, S. \& T. Sase. 1969. Formation of iodide-iodine in the ocean. Deep-Sea Res., 16: 489-496.

Ullman, W.J. \& R.C. Aller. 1980. Dissolved iodine flux from estuarine sediments and implications for the enrichment of iodine at the sediment water interface. Geochim. Cosmochim. Acta, 44: 1177-1184.

Ullman, W.J., G.W. Luther, G.J. De Lange \& J.R.W. Woittiez. 1990. Iodine chemistry in deep anoxic basins and overlying waters of the Mediterranean Sea. Mar. Chem., 31: $153-170$

Wong, G.T.F. \& P.G. Brewer. 1977. The marine chemistry of iodine in anoxic basins. Geochim. Cosmochim. Acta., 41(1): 151-159.

Wong, G.T.F. \& X.H. Cheng. 1998. Dissolved organic iodine in marine waters: determination, occurrence and analytical implications. Mar. Chem., 59: 271-281.

Wong, G.T.F. \& X.H. Cheng. 2001. The formation of iodide in inshore waters from the photochemical decomposition of dissolved organic iodine. Mar. Chem., 74: 53-64.

Wuilloud, R.G., J.C.A. de Wuilloud, A.P. Vonderheide \& J.A. Caruso. 2003. Determination of iodinated phenol species at parts-per-trillion concentration levels in different water samples by solid-phase microextraction/offline GC-ICPMS. J. Anal. Atom. Spectrosc., 18: 1119-1124.

Žic, V. \& M. Branica. 2006. The distributions of iodate and iodide in Rogoznica Lake (East Adriatic Coast). Estuar. Coast. Shelf Sci., 66: 55-66.

Received: January 2009

Accepted: June 2009 